\author{
ANNA MALMQUIST \& \\ ALEXANDER SPÅNBERG EKHOLM
}

\title{
Swedish Gay Men's Pursuit of Fatherhood
}

\author{
Legal Obstacles and Strategies for Coping with Them
}

\begin{abstract}
The aim of the present work is to explore how gay fathers have experienced legal obstacles throughout their process of becoming fathers, and what strategies they have used to cope with the difficulties they have met. The study used semi-structured interviews to capture the fathers' experiences, and a constructivist grounded theory to analyse the data. Interviews with thirty gay fathers in Sweden were included in the study. The participants had become fathers through surrogacy, shared parenthood with women, or foster care. Legal obstacles had played a prominent role in all three family forms, as well as in adoption - which some participants had unsuccessfully pursued. Obstacles marked both their pursuit of fatherhood and their establishment of legal custody. Some participants had eventually given up their initially preferred path to parenthood and searched for another route. To overcome legal obstacles, the participants had utilised one or more strategies; such as being persistent and well prepared, pretending to be straight, and finding access to assisted reproduction treatment abroad. Regardless of the path to parenthood, the participants stressed the necessity of possessing adequate personal or economic resources to become parents.
\end{abstract}

Keywords: gay father, legal obstacles, LGBT family, surrogacy, shared parenting, foster care 
CONTEMPORARY SWEDISH FAMILIES show great diversity, with about $25 \%$ of children living in constellations other than the heteronormative nuclear family at age $\mathrm{I} 7$, that is in single-parent households, or with a parent and a stepparent (Statistiska centralbyrån 20I2). Lesbian, gay, bisexual, and transgender (LGBT) families are part of the diversity, with gay male parenting couples being a small but growing group (Aldén et al. 2015). Legal changes concerning same-sex relations and parenting have created important milestones, with registered partnership in 1995, same-sex adoption in 2003, assisted reproduction treatment (ART) for female couples in 2005, a gender-neutral marriage act in 2009, and termination of forced sterilisation as a requirement for legal gender reassignment in 2013. However, remaining restrictions on ART, and major difficulties in carrying through an adoption, entail comprehensive obstacles for gay male couples with a desire to parent. The present article focuses on the legal obstacles faced by gay male parenting couples in their pursuit of fatherhood.

\section{Family Law}

According to Swedish law, a child can have one or two legal parents, that are often but not always the legal guardian(s) (SFS I949:38I, chapter I and 6). A person who gives birth is automatically established as the child's legal parent and guardian, and the genetic father is usually established as the second legal parent. If the birth mother and the genetic father are not married to each other, the birth mother will initially have sole custody. With a joint assignment, the legal parents may agree to share custody or express their wish that the father should have sole custody.

Family law is not a neutral set of rules, but rather expresses norms about what a family is or should be (Mägi and Zimmerman 2015). The principal rule for establishing legal parenthood is based on married heterosexual couples that conceive though intercourse. In contrast, LGBT families are covered by a patchwork of exception rules. In Sweden, female couples, single women, and transsexual men have access to ART through public healthcare, while cisgender male couples and singles do not (SFS 2006:35I). 


\section{Pathways to Parenthood}

For male couples, available paths to parenthood require that someone external to the couple give birth to the child. Some paths (adoption and foster care) entail parenting of an already born child, while others (shared parenting and surrogacy) are realised by conceiving a child.

An adoption means that the child acquires one or two new legal parents and guardians, as the adoptee becomes the legal child of the adopter(s) rather than of the biological parents (SFS 1949:38I, chapter 4). An adoption process is comprehensive and puts great demands on the adopters. Adoption has been legal for same-sex couples in Sweden since 2003 (Malmquist 2016), but in reality, very few same-sex couples have been able to adopt, partly because of the limited access to foreign organisations that accept same-sex adopters. The first transnational adoption to a Swedish male couple occurred in 2017 (Adoptionscentrum 2017). Of relevance to many same-sex couples is also the possibility of secondparent adoption, which involves the spouse or cohabitant of the legal parent adopting the child (SFS I949:38I, chapter 4).

Most adoptions in Sweden are transnational, as domestic adoptions are rare (Socialstyrelsen 2014). Instead of adoption, foster care is arranged when the legal parent(s) are not able to satisfactorily care for the child (SFS 2001:453, chapter 6). Stable, solid couples and singles in Sweden may function as foster parents, regardless of their gender. The intended foster parent(s) must undergo an extensive assessment, similar to that of an adopter, before being approved. With a foster care arrangement, strong legal bonds are kept between the child and its biological parents. The need for foster care placement is regularly reassessed, and the child may return to the biological parents if foster care is no longer considered necessary. The biological parent(s) typically remain legal guardian(s) during the foster care placement. However, legal custody may be transferred to the foster parents upon a court decision, which often takes place after three years of foster care.

A shared parenting arrangement between friends is one potential pathway to parenthood for gay men. Previously, shared parenting arrangements have been a relatively common route to parenthood for LGBs, 
but since lesbian couples gained access to ART in Swedish healthcare, they typically choose to raise the children on their own (Malmquist 2or6). Shared parenting often involves more than two social parents, but only two of them can be the child's legal parents/guardians. If the child is conceived through home insemination, Swedish law considers the genetic parents to be the legal parents. ARTs are not accessible for those that wish to share parenting with a friend, but a lesbian couple or a single woman may bring their friend to the clinic as a known sperm donor with no legal claims to parenthood (SFS 2006:35I).

A surrogacy arrangement means that a person becomes pregnant and gives birth to the child, with the intention of leaving the child to its intended parents after the delivery. Surrogacy may be altruistic, when the surrogate mother is paid only for her pregnancy and childbirth expenses, or commercial, when she is paid for the surrogacy itself (SOU 2016:I I). In the case of gay male couples, sperm is generally given from one of the intended fathers. In a traditional surrogacy arrangement, the egg is the surrogate mother's own; but more commonly, a separate egg donator is utilised, in a gestational surrogacy arrangement. An egg donation requires that vitro fertilisation (IVF) be conducted at a fertility clinic. Swedish fertility clinics are prohibited by law from engaging in ART for surrogacy arrangements (SFS 2006:35I), but couples and singles may access clinics abroad for the procedure. A traditional surrogacy pregnancy may be conceived through home insemination. According to Swedish law, the gestational mother is considered the legal parent at birth, and any kind of agreement between the involved parties before birth will lack legal validity (SFS I949:38I, chapter I and 4 ). The genetic father may be established as the legal father and may share or take over custody. Thereafter, the non-genetic father may apply for second-parent adoption, and once granted, he becomes the child's legal parent/guardian instead of the surrogate mother. Another potential path to joint legal parenthood arises if the fathers have a court decision from the country where the child was born, where they are established as the legal parents (SOU 20I6:II). In that case, the court decision may be upheld by a Swedish court. 


\section{Previous Research on Gay Fathers}

Research on LGBT families has focused primarily on lesbian mothers, while gay fathers have received less attention, in Sweden and internationally (Golombok and Tasker 20I I; Carneiro et al. 2017). Most research on gay father families has been conducted in Western countries, a majority originating from the United States, with the typical participants being upper-middle class men that became fathers through surrogacy or adoption (for an overview, see Golombok and Tasker 20I I; Carneiro et al. 20r7).

Some studies have focused on motives when choosing pathways to parenthood, showing that adoptive parents often display ideological motives for their choice to adopt, such as a desire to give a vulnerable child a loving home (Berkowitz 20I I; Goldberg et al. 20I2). People that become parents through surrogacy or through shared parenting, often share a desire to carry on their genes or raise a child from infancy (Folgerø 2008; Erera and Segal-Engelchin 2014; Ziv and Freund-Eschar 2015). Men that become fathers through shared parenting also claim that the presence of a mother is important to them (Erera and Segal-Engelchin 20I4). Legal aspects have affected the choice of route to parenthood for some men, where adoption is generally considered more difficult to accomplish than surrogacy (Ziv and Freund-Eschar 2015).

Gay men often perceive the pursuit of fatherhood as strenuous, both emotionally and economically (Berkowitz 20Ir; Nebeling Petersen 20I8). At some point in their life, many assumed that parenting would be impossible for them to achieve.

Research has also focused on how gay fathers experience contact with professionals, for example in healthcare, schools, or preschools (Goldberg and Smith 2014; Vinjamuri 2015; Andersen et al. 2017). While healthcare professionals often are depicted as deficient in their contact (Vinjamuri 2015; Andersen et al. 2017), a more positive experience is often described with regard to preschool encounters (Goldberg and Smith 2014).

Only a few researchers have focused on gay fathers in Sweden. Karin Zetterqvist Nelson (2006) and Jesper Andreasson and Thomas Johansson 
(2017) have discussed gay men's fatherhood as challenging hegemonic masculinity, as they adopt nurturing and caring parenting roles. Participants in Andreasson and Johansson's (2017) study depicted their pathway to parenthood as complicated, including practical, relational, and legal strains. A Swedish study on surrogacy arrangements, with gay male and heterosexual couples as participants, revealed that most couples viewed surrogacy as their last resort in their desire for parenthood (Arvidsson et al. 2015). Several participants expressed their desire for legalisation of ART in surrogacy arrangements in Sweden, to increase options for childless couples and, in their view, diminish the risk of exploiting poor women.

\section{Heteronormativity Affects Gay Men's Family Making}

Heteronormativity has a great affect on ideas about intimate relations and family making (Herz and Johansson 20I5; Malmquist 2015). LGBT families both face and challenge cultural ideas about what is construed as "natural," for example the idea of parenthood presupposing heterosexual intimacy, or that a child needs a mother and a father (Folgerø 2008). Social norms are generally accompanied by consequences for those that challenge the norms. Minority stress is one such consequence, meaning that people in minority groups often experience increased stress related to discrimination and a fear of being treated badly (Meyer 2003). Gay fathers have described how others may react with confusion or suspicion when they meet a two-father family (Vinjamuri 2015; Nebeling Petersen 2018), and how professionals in schools, preschools, and healthcare make heteronormative presumptions when they meet gay parents (Goldberg and Smith 2014; Andersen et al. 20I7). Though facing heteronormativity, many gay fathers are open about their family form in their daily life, and being open is often considered more important as a gay parent than as a gay individual or same-sex couple (Armesto and Shapiro 2011).

As mentioned previously, Swedish gay male couples face comprehensive legal obstacles when searching for a path to parenthood (Andreasson and Johansson 20I7). The present article aims to explore in more detail 
how gay fathers have experienced legal obstacles throughout their process of becoming and being fathers, and what strategies they have used to cope with the difficulties that have arisen.

\section{Methodology}

\section{Constructivist Grounded Theory}

The present study draws on constructivist grounded theory (CGT), a method developed from traditional grounded theory by Kathy Charmaz (2or4). Theoretically, CGT rests on symbolic interactionism and social constructivism. It is assumed that human actions construct the self, social reality and society, that people's actions affect the situation, and vice versa. The main difference between CGT and traditional grounded theory (GT) regards epistemology; while traditional GT rests on realistic epistemology, CGT recognises that a study's results, participants and researcher(s) are products of the social, cultural and historical context in which they exist (Charmaz 2014). The research process is seen as coconstructed by the researcher and the participants (Charmaz and Henwood 20I7). Charmaz (2014) means that the methodological steps taken in GT are not dependent on any specific epistemological assumptions, but such assumptions influence how the steps are performed and how the results are interpreted. A difference between traditional GT and CGT is that the former views codes and theory as inherent in the data, while the latter views codes and theory as constructed. A study is seen as an interpretation of a part of the world, not an objective truth (Charmaz 20r4).

CGT is an inductive method, meaning that the researchers start from the data to build the theory (Thornberg and Charmaz 2013; Charmaz 20I4). It is also an abductive method, as the researchers constantly challenge their constructed analysis. The researchers work with data collection and analysis in parallel.

\section{Data Collection}

In the present study, semi-structured interviews provided the data. An interview guide intended to capture the interviewees' views on, and experiences of, several aspects of parenthood was used. Seventeen 
interviews were conducted with thirty fathers in same-sex relations (thirteen interviews with couples and four with individuals). Two of the interviews were initially conducted by Anna Malmquist in 2010 as part of a broader research project on same-sex parenting (Malmquist 2015). These two interviews were later utilised as a pilot study when Malmquist applied for funding for a focused research project on gay father families in Sweden. This project was funded by Forte in 2017 and approved by regional ethics board at Linköping University the same year. Additional data were collected thereafter, in 2018. Nine interviews were conducted by Alexander Spånberg Ekholm and Sonja Höjerström, and additional six interviews by Anna Malmquist.

Recruitment of participants was conducted primarily through social media. A Facebook group for gay fathers, RFSL (the Swedish national association for homosexual, bisexual, transsexual and queer rights) and the Swedish podcast Bögministeriet (a podcast by and for homosexual men) spread out recruitment ad through their social media channels and websites. The researchers also shared the ad on their private Facebook accounts. Lastly, snowball recruitment was used, where the interviewees were asked to inform acquaintances and friends about the study. The ad informed briefly about the study and asked interested couples to contact the researchers to obtain more information. Interested couples obtained an information letter by e-mail and were then contacted by telephone or e-mail to schedule an interview. The couples themselves were able to decide the location and time for the interview to facilitate participation, to the extent possible.

The interviews were between 45 and 120 minutes long and were conducted in the interviewees' homes (fifteen interviews) or in public cafes (two interviews). In total, the interviews resulted in 1,463 minutes of recordings. The interviewees were assured that they would remain anonymous, that they had the right to discontinue their participation at any time, and that they had the right to refuse to answer questions. Before the interview, the participants were also informed about the structure of the interview, the purpose of the study and in what form the results would be published. The interviewees gave their written 
informed consent to participate. The interview focused on their path to parenthood, everyday life as a parent and the relational aspects of parenthood.

\section{Transcription and Analysis}

All interviews were transcribed verbatim. Names have been replaced with pseudonyms. The interviewees were given an opportunity to read their own transcript and to request that specific parts of the interview be removed. A few of the interviewees took this opportunity.

Coding of data was performed in three steps, following CGT: initial, focused and theoretical coding. Initial coding, line by line, was conducted on five interviews by Spånberg Ekholm. During this phase, constant comparison was practised. The researcher strived to code the chunks of data as actions, in order to identify social processes and see the interviewees as agents in the social world (Charmaz 2014).

During the focused coding, Spånberg Ekholm selected codes representing the most central issues for the interviewee and of relevance to the research question and let these codes guide the continued coding. When eight focused codes with a set of secondary codes had been constructed, four additional interviews were coded using these focused codes. Constant comparison and constant adaptation of the codes to better fit the data were continuously conducted.

Memo writing is an important part of the analytical process (Charmaz 20I4). Memos serve to collect ideas, hypotheses, definitions of codes and categories, tentative associations between categories and personal reflections that allow the researchers to reflect on their own influence on the research process. All in all, sixteen memos were written during the coding process and utilised to form the grounded theory.

Theoretical coding means that an analysis is made of how the codes and categories relate to each other and of what type of relationship they have (Charmaz 20I4). During this phase, the categorising and sorting of the focused codes started, the goal being to construct their relationship to each other. It is important to not force the data into pre-existing theoretical concepts during the coding process, but when the researcher 
has an analysis of the data, a draft of the theory, the researcher compares pre-existing theories and literature to the grounded theory (Charmaz 20I4). During this phase, the researcher checks what pre-existing theories and concepts that relate to the grounded theory. In this case, the grounded theory was constructed by the authors and checked against the data, memos, and codes to determine that the theory fit the data. The remaining eight interviews, as well as pre-existing theories and concepts such as heteronormativity and minority stress, were used to check the relevance of the theory. The theory was modified when the new data called for adaptation of the model. The data collection can be considered as saturated, as the researchers were able to construct a theory that adequately explained what was happening in the collected data.

The analysis resulted in four models focusing on possibilities for and obstacles to gay men becoming parents and living as families in Sweden, and their strategies for coping with the obstacles they met. The complete grounded theory is presented in Spånberg Ekholm's master's thesis (Spånberg Ekholm 2or8). For the present article, a small part of the results has been selected for a more detailed focus on legal obstacles.

\section{Participants}

The thirty participants were between 33 and 55 years old, most of them in their forties. The fathers had between one and three children, between four months and 18 years of age at the time of the interview. Thirteen of the couples had become parents through surrogacy arrangements, ten through agencies in the United States, one through a European agency, and two through home inseminations. Two of the couples had children through shared parenthood, and additionally two couples had become parents through foster care. Twelve couples resided in large Swedish cities, one couple in a suburban area, one in a small town, and two couples in middle-sized cities. Further, one of the couples lived in a small town in another Western European country. A majority of the participants had a university-level education and a minority had a high school-level education only. 


\section{Result}

Many interviewees described having had a strong desire to be a parent. For some of them, the longing for children had been long-lasting and intense, while others reflected on a desire that had grown gradually, sometimes evoked by their partner's wish to start a family. On their journeys to becoming fathers, all parents had met with obstacles, which for some had delayed their parenting or pushed them to find another path to parenthood. The obstacles included both external factors, such as legal restrictions, and internal factors, such as lack of personal resources, and their own practical and ethical considerations, or doubts about having a child as gay fathers in a heteronormative society. In the present analysis, we focus on the legal obstacles the participants have faced, as well as on their descriptions of how they were able to overcome or get around these obstacles. Initially, we will focus on the legal obstacles that arose when the participants decided to become parents (Figure I). Thereafter, we will focus on obstacles concerning legal custody (Figure 2).

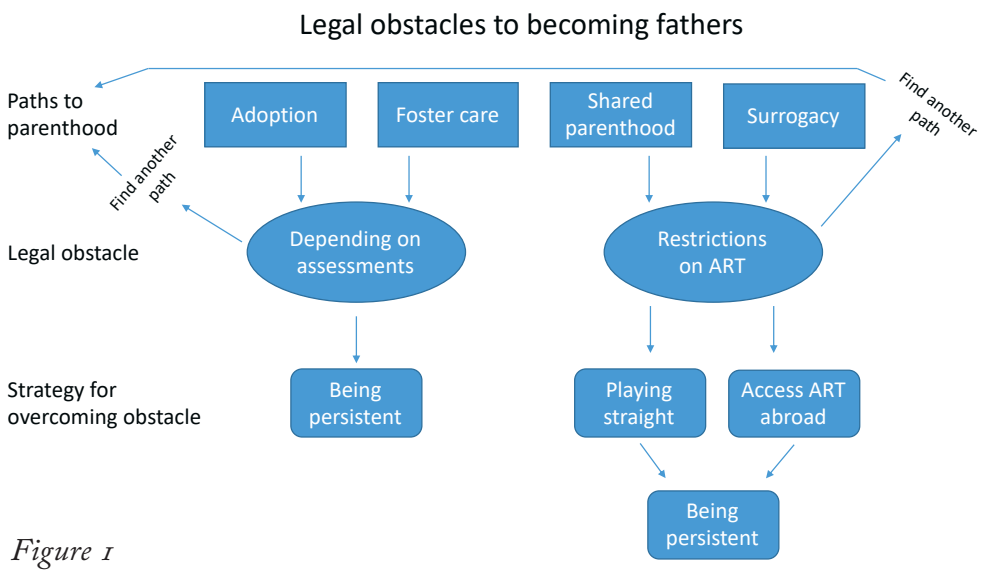

\section{Legal Obstacles to Becoming Fathers}

Most participants described how they had faced legal obstacles to becoming fathers. For those that aimed to raise a non-genetically related 
child (through adoption or foster care), obstacles concerned their dependency on an assessment. For those that aimed to conceive a child (though shared parenting or surrogacy), legal obstacles concerned restrictions in ART.

\section{Depending on Assessments}

A couple wishing to adopt must contact their local social agency and undergo an extensive assessment before being approved as future adoptive parents. Passing the assessment is therefore the first legal obstacle to overcome. Thereafter, the couple asks an authorised adoption agency to mediate an adoption for them. Several participants told us that they had initially discussed the ability to adopt; Adrian and his partner had gone through the assessment at the social agency and had been approved for adoption. Thereafter they contacted an adoption agency. Adrian described how their case was handled:

And then we got - we emailed the adoption centre and wanted to get on the waiting list, but they recommended that we not apply because our case wouldn't be prioritised (Interviewer: oh) and that was like the first time we experienced, well, discrimination.

(Adrian, father through surrogacy)

According to Adrian, the adoption agency had discouraged them from continuing their process. According to Swedish law, adoptions may only in exceptional cases be arranged without an authorised agency (e.g., when there is already a personal relation between the child and the adopter). Their ability to adopt was therefore dependent on an agency, and the agency's denial turned out to be an obstacle for them. Realising that adoption was a blind alley, the couple sought another path to parenthood. All couples that had initially aimed to adopt had come to the conclusion that they could not proceed, and had searched for other routes.

Two couples had eventually sought to engage in foster care and had found this to be a viable path to raise children. Both couples described 
having placed an announcement in a national forum for foster care agencies, where they presented themselves and their desire to become foster parents. Stefan explained how he and his partner, Nils, had been contacted by a couple of foster care agencies.

They sounded very professional; it was a private company (Interviewer: uh huh). But, uh, then, we said we were same-sex (Nils: yeah), you know, so they would understand we were a same-sex couple, two guys like, living in a house, and then they never got back to us.

(Stefan, father through foster care)

Despite the general shortage of suitable foster families in Sweden, the couple had left their announcement up for a couple of years before being contacted by the social workers who, in the end, approved them as foster parents. Simply getting to the assessment had therefore been a long journey for them. The assessment process itself had also been comprehensive and stressful. In order to cope with the stress, Stefan and Nils explained how they had kept low expectations of being approved as gay male foster parents, so that they would not be too disappointed if they did not pass. Once approved for foster care, however, both couples had been matched with their foster children quickly.

A great deal of persistency is visible in the narratives by the parents of foster children. By mobilising persistency, they had been able to continue throughout the process and overcome obstacles, despite setbacks. Thus, for these parents, persistency can be described as the central strategy for overcoming legal obstacles.

\section{Restrictions on Assisted Reproduction Treatment}

Unlike the two couples with foster children, the remaining participants had started biological families. A few of them had been able to conceive through home inseminations, without medical professional treatment. Most participants, however, had required help from fertility clinics to become parents. For them, the limited access to fertility treatment in Swedish healthcare was the first legal obstacle to overcome. 
The couples that engaged in gestational surrogacy arrangements required an IVF treatment at a fertility clinic. As ART is not allowed at Swedish clinics in surrogacy arrangements, their strategy for overcoming this obstacle was to visit clinics abroad. They often described the importance of having friends or acquaintances that had gone through an international surrogacy before them. Lars described how his friend had shared advice on surrogacy:

Then [friend's name], who's a very structured man, he had, went through his files, and exactly what they had done. So, we contacted the same agency, that is [name of agency], and all that. So, in many ways we've been copy cats, and they've broken the ground and uncertainty for us, you could say. We felt, well we didn't feel like pioneers, in the same way, who had to figure everything out from the start, instead there was someone we could ask, who was, who was also close to us. That felt really good.

(Lars, father through surrogacy)

For Lars and his partner, their friends had given them a sense of confidence throughout the process. Besides having good contacts, the intended parents must also have the financial ability to proceed with a surrogacy arrangement abroad, as it is highly expensive (SOU 2016:II). Gestational surrogacy had therefore only been an option for uppermiddle class couples. Furthermore, several participants emphasised the importance of having the appropriate personal qualities to successfully manage a surrogacy process. Martin explained:

It's really required a lot of energy and even when both you and I are pretty good at communicating, both verbally and in writing, but I don't think everybody has the strength or ability to carry a process like this through. (Martin, father through surrogacy)

Martin highlighted the energy that was needed to go through the long and complicated surrogacy process. Others mentioned the importance 
of being well structured and orderly. Their experiences reveal the importance of persistency in overcoming the legal obstacle of not having access to ARTs domestically.

Limited access to ART also affected one couple that had children together with a female couple. As fertility treatment in Sweden is not accessible for friends in shared parenting engagements, the couples faced an obstacle when the intended birth mother did not become pregnant through home insemination. When denied treatment at the first clinic, they turned to another clinic and pretended to be a heterosexual couple. Johannes explained how he felt about this:

The whole thing was just so bizarre, that you have to go there and pretend like (Interviewer: right) like, I remember sitting in the waiting room with Liat there [...] and like: "What if they understand that we're not together like and I have to pretend to be straight?" (laughs) Completely sick really (Nore: uh huh) that you have to do that at all. (Johannes, father through shared parenting)

For Johannes it had felt awkward to pretend to be in an intimate relationship with his female friend. In order to achieve fertility treatment in Sweden, lying was their only option. In this case, a great deal of persistency was also required to finally get the desired treatment.

\section{Legal Obstacles to Gaining Legal Custody}

As shown above, most participants reported having had the experience of navigating different legal obstacles in order to become fathers. Once a child had been born, or, in the case of foster care, been placed in their family, most couples faced additional legal obstacles. The most prominent were issues of legal custody.

For the participants, the process of gaining legal custody had been prolonged, from a few weeks to several months or years, depending on the family form. Non-genetic fathers in shared parenthood were not likely to ever become custody holders. In the following, we will show how the parents depicted obstacles that arose when they were not cus- 
tody holders: being denied parental rights, and uncertainty. Thereafter, we will focus on obstacles that arose when the participants sought to become custody holders: lingering processes and being dependent on caseworkers or assessments.

\section{Legal obstacles to achieving legal custody}

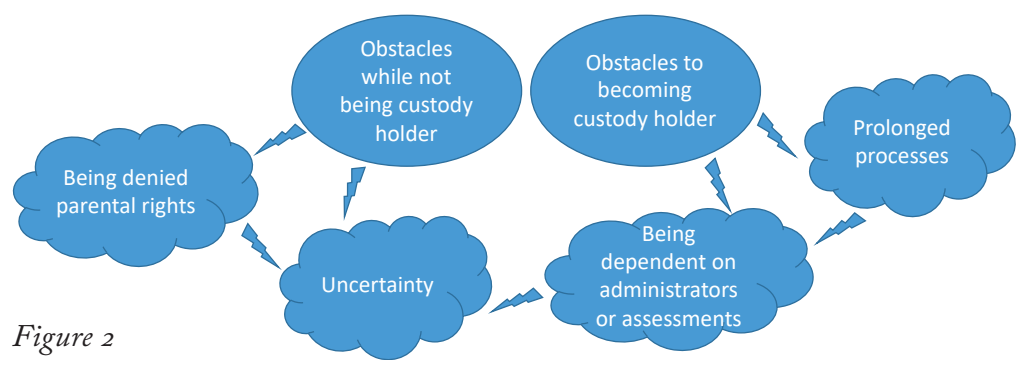

\section{Being Denied Parental Rights}

A minor child is supposed to be represented by its legal guardian in issues that concerns the child's wellbeing. For the participants that raised children without being their legal guardians, this caused problems. Nore and Johannes shared parenting with a lesbian couple and explained the juridical complications:

Nore: Then there are other laws involved too, because, uh, because my three children aren't biological children or that I have custody that affects other laws you know like inheritance rights for example, all of the children, all of my children won't inherit from me alike based on like the first issue plus, you know, access to, well, but silly things like the pharmacy or uh parental leave, that we've partly solved because Johannes: We get around it -

Nore: - live together and you know SIGH are married, but it's not that automatically because it's my child like Johannes: You don't have rights in the same way. (Nore and Johannes, fathers through shared parenting) 
For Nore and Johannes, being married and providing each other with power of attorney had helped them to navigate the obstacles. Because they were married, they could transfer parental leave from the legal parent to his spouse, and with power of attorney they were able to legally represent their children without being custody holders (i.e., picking up the child's medicine from the pharmacy). Still, they stressed their frustration about the fact that not all four social parents could share custody.

For parents that care for young children, parental leave is particularly important. In Sweden, parental leave is granted to all legal parents with legal custody, but foster parents or social parents without custody are not included in the parental leave insurance. Stefan described how he was denied time off work when his foster child arrived.

Stefan: They, they denied me any - all the way up. I appealed my boss's decision. (Interviewer: yes) And said "That's crazy!" (Interviewer: mm)

"Christ, I sit by a, a, a guy who got paternity leave when he got a dog!" For real, I'm not making this up, this is the truth Interviewer: $\mathrm{He}$, the person you sit by, got a leave of absence Stefan: Got a dog and got, got to take paternity leave because he got a dog, but I wasn't allowed to be at home with my child, who was going to be in my family.

(Stefan, father through foster care)

Because foster parents have no established right to parental leave, it is up to the employer to decide whether a foster parent may take time off work to care for the child. In Stefan's case, his application was denied. However, the employer has no obligation to allow time off work when an employee gets a dog either, though Stefan's colleague was granted time off to care for his puppy. Stefan interpreted the different treatment as an expression of hatred towards him and his family. Instead, his partner stayed home on a full-time basis. 


\section{Uncertainty}

Several parents described the uncertainty they had dealt with before they were established as legal guardians. The stress was most prominent in the foster parents' narratives. A child who has been put in foster care may, based on the social worker's decision, be transferred to its biological parents or placed in another foster family. Robert talked about the stress this had entailed for him:
But there's a downside too when you [pause] there, I think, any parent would feel bad knowing that for, like now anyway for three years, (In- terviewer: uh huh), not having for sure. (Interviewer: uh huh). Knowing that no one will come and take the child away from you, even though, though you're maybe great parents (Interviewer: uh huh), but that the child won't just disappear form you.
(Robert, father through foster care)

Robert described the vulnerably he felt as a foster parent, when he had committed his love to a child with no guarantees that the child would stay with him throughout its childhood. The likelihood that a child will be moved from its foster parents decreases if custody is transferred to the foster parents. Therefore, both couples with foster children talked about their desire for a custody transfer.

\section{Prolonged Processes}

Except for the non-genetic fathers in shared parenting, most participants had gained legal custody eventually. Several interviewees, however, did share their frustrations about the often-lengthy period before legal parenthood and custody have been established. For parents in surrogacy arrangements, the process could last for several months. Anders explained the legal troubles he faced after coming home with his child:

Well, first I wasn't even given custody when I came home, instead it was sole custody for the mother, even though I had sole custody in the US that decision didn't apply in Sweden, so I couldn't take out my parental 
allowance because I couldn't log in to the social insurance site, but only the mother can and she has to give the father permission. And since she hadn't g- didn't have a personal id number, a Swedish one, then she couldn't log in either so I couldn't get my parental allowance uh, the tax authorities just said I didn't have custody, so I got nothing from them, uh, the migration board messed up my papers, they got stuck at I don't know how many places [...] So, I had to call and make inquiries everywhere [...] Anyway, in the end she [daughter] got her Swedish citizenship, because the migration people acknowledged paternity [...] She was born in the summer and I think I got custody in November or December.

That's how long it took.

(Anders, father through surrogacy)

Anders described the disagreement between American and Swedish law on how to judge their case. While the American authorities had given Anders sole custody, Swedish authorities still considered the American surrogate mother the legitimate custody holder. In practice, this meant that Anders's daughter lived in Sweden with her father for several months without being a Swedish citizen, without personal identification number, and without a legal guardian.

Several interviewees described a long wait before legal parenthood was established for the genetic father. For the non-genetic father, the process of becoming a legal parent was initiated first thereafter, in a second-parent adoption process. This process, in turn, could draw out for additionally several months. One couple, Thomas and Fredrik, described their frustration over the lingering adoption process, and explained that they had decided to call the court administrator daily as an attempt to push the decision through. Their persistency provides some insight into the importance of shared legal parenthood and custody for the couple.

\section{Being Dependent on Caseworkers or Assessments}

In order to be established as the child's legal parents and gain custody, the fathers had approached caseworkers at various Swedish authorities (the local social agency, the district court, the tax agency, and the mi- 
gration agency), depending on their path to parenthood. Some interviewees depicted the authorities' treatment of their case as a lottery and claimed that their treatment had depended on what caseworker they encountered. Some also talked about negative attitudes, as they believed that they had been badly treated due to the caseworkers' negative attitude towards their family form. Anders explained his frustration when approaching the social agency:
Before you know it started with, contacting X Municipality where I lived. I wrote fourteen emails and called and left messages ten times to the family law office in X Municipality [...]. At last I called a, once when I called somebody happened to answer [laughs] who thought it was really problematic. Because they said: "We don't deal with surrogate children, so we don't want to answer any questions or have anything at all to do with this."
(Anders, father through surrogacy)

Like many other participants, Anders came to realise that Swedish authorities are unprepared to handle surrogacy arrangements. Several participants described how different caseworkers had given them contradictory information, and some participants depicted a limbo situation in which various authorities had referred their case between them. Most participants described how they had handled these situations with persistency and by being well-informed and eager to push their case further.

For the non-genetic fathers, pursuit of custody generally involved an assessment of their suitability as fathers. In the case of foster care, it was the social workers' assessment that determined when a custody transfer to the foster parents was considered suitable, and both couples with foster children expressed how they had wished for an earlier transfer. In the case of surrogacy, most non-genetic fathers had conducted a second-parent adoption, where their parental ability and the stability of their marriage had been assessed. While some participants commended the social workers for handling their adoption case smoothly or quickly, others expressed their frustration about the assessment: 
Thomas: And they questioned us you know rather - or I mean they didn't doubt us, but they asked a lot about, about female role models (Interviewer: okay), and I said: "I have a strong mother, Fredrik has a sister, we have faghags -"

Fredrik: "My mother -"

Thomas: "We have so many female strong role models in our family, so it's not a problem in the least for Linnéa [daughter]," we said. I guess that's, that's what they were most worried about.

(Thomas and Fredrik, fathers through surrogacy)

The social workers' questions about having female role models point at a core difference between how legal fatherhood and custody is established for a genetic father and for his partner. While Fredrik gained his status as legal parent and custody holder based on his genetic fatherhood, Thomas had to undergo an assessment in which the couple was questioned about the suitability of having two male parents before his legal fatherhood and custody could be established. The assessment thus becomes a legal obstacle to overcome to achieve joint custody. But if the adoption were not approved, the child would still grow up with the couple, regardless of any potential "lack" of female role models.

\section{Discussion}

Our results show that gay male couples face comprehensive legal obstacles throughout their processes of having children and gaining legal custody, thus echoing previous research where gay men's pursuit of fatherhood has been described as strenuous (Berkowitz 20Ir; Andreasson and Johansson 20I7; Nebeling Petersen 2018). Reflecting previous research on gay fathers (Carneiro et al. 2017), most of our participants are privileged upper-middle-class men, whose personal and financial resources, together with a great deal of persistency, have enabled them to overcome these obstacles.

Swedish laws on adoption, second-parent adoption, and foster care are neutral towards the gender and marital status of the intended parents (SFS 1949:381, chapter 4; SFS 200r:453, chapter 6). Still, the 
participants wishing to adopt described that route as a dead-end. Authorised adoption agencies have often claimed that they have no foreign partners that are willing to mediate adoption for same-sex couples (e.g., Haverdahl 2002). However, it has also been argued that the adoption agencies have been reluctant to establish such contacts (Haverdahl 2002), reflecting their generally strong opposition to the legislation on same-sex adoption (Malmquist 2007).

The difficulties experienced by one couple when announcing for foster children may reflect a similar reluctance in relation to same-sex parents. It has been shown previously that social workers are hesitant about approving same-sex foster parents, based on clear heteronormative arguments, such as that same-sex parents would be a source of stress for the child (Jonsson and Karrman 2007). Due to foster parents' weak legal position, one participant had also been denied time off from work to care for his child. The employer's denial was interpreted by the couples as a homophobic act, but regardless of the employer's motives, the situation calls attention to the need for improvement in foster parents' legal situation.

In our study, all participants with an initial ambition to adopt had eventually sought other paths to parenthood. While only a few engaged in foster care, most of them choose surrogacy, thus echoing previous findings showing that adoption is more difficult for gay men than surrogacy (Arvidsson et al. 2015; Ziv and Freund-Eschar 2015).

While ART is accessible for cohabiting or married couples and singles with childbearing capacity, it is not accessible in the case of surrogacy or shared parenting between friends (SFS 2006:35I). It has been argued that such restrictions reflect heteronormativity in the law (Juvas and Westerlund 2008; Mägi and Zimmerman 2015). The exclusion of friend constellations from ART has not been the subject of any governmental investigation and is likely simply a reflection of the heteronormative presumption that children should preferably be raised by intimate couples. The question of surrogacy, however, has been the subject of multiple investigations, where the pros and cons of legislation have been discussed (Statens medicinsk-etiska råd 2013; SOU 2016:II). 
Arguments against surrogacy have generally not concerned the gender or sexuality of the intended parents, but rather focused on preventing the exploitation of potential surrogate mothers. In contrast, the gender composition of the parents was highly central in the debate against same-sex adoption and ART for lesbian couples, before these practices were legalised (Malmquist and Zetterqvist Nelson 2008). Furthermore, most of the Swedish couples that have children through surrogacy arrangements abroad are heterosexual (SOU 2016:II). Therefore, we argue that the prohibition of surrogacy is not heteronormative a priori, though it greatly affects gay men.

Several participants that became fathers through surrogacy depicted a limbo situation where their case had been referred between authorities. Some participants perceived this reluctance as an expression of caseworkers' personal disapproval of their family form, echoing previous research showing inadequate treatment of gay father families in other settings, such as healthcare (Andersen et al. 20I7). The participants' narratives indicate the need for established routines for surrogacy errands. Caseworkers are entitled to their own personal views, but solid routines are required and must be followed to ensure legal security for parents and children. Most importantly, the children are kept in a legal vacuum with no legal guardian until their case is handled. Prolonged administrative processes therefore ultimately affect the children.

As concerns establishing legal parenthood for a newborn child, there is a patchwork of different rules applicable in different situations (SFS I949:38I, chapter I). Shared legal parenthood and joint custody from birth are only granted to married different-sex couples - whereas others are subjected to the complexity of exception rules. It has been claimed that this unique advantage for married different-sex couples reflects a heteronormative bias in family law (Mägi and Zimmerman 2015).

There are different paths to legal parenthood applicable for the genetic father vis-à-vis his partner. With few exceptions, Swedish law considers a genetic father to be the legitimate father, and will establish his fatherhood, although the procedure is more intricate when the genetic father is not partnered with the birth mother, and when the child is 
born abroad (SFS 1949:38I, chapter I and 2; SFS 1985:367). For the partner of the genetic father, there is no granted access to legal parenthood at all. He is allotted to a second-parent adoption or a verification by a foreign court decision, which both are dependent on the ruling of a Swedish court. An upcoming legislative change has been set to ease establishment of legal fatherhood for the genetic father, when children are born as a result of surrogacy abroad (Prop 2017/18:155). However, no similar facilitations are made for the partner.

The non-genetic parents in shared parenting arrangements have a particular vulnerability in relation to family law, because the child will bond to more social parents than the allowed number of legal parents/ guardians. The possibility of allowing more than two legal parents or guardians has not been the subject of any governmental investigation, which is most likely a reflection of heteronormative family ideals.

Heteronormativity has been shown to greatly affect intimate relations and family making, entailing that LGBT individuals with a desire to parent meet obstacles (Herz and Johansson 2015; Malmquist 2015). The present work shows that the obstacles faced by gay men in their pursuit of fatherhood can partly be understood in relation to heteronormative legislation.

\section{Conclusions}

Swedish gay men face comprehensive legal obstacles when aiming at fatherhood. Depending on the route to parenthood, different obstacles arise. Laws on adoption and foster care are neutral to the adult's gender and marital status, but prospective parents are dependent on assessments, where a great deal of persistency seem to be necessary for gay men to pass. Restrictions on ART hinder gay men from starting biological families, but such obstacles can be rounded as men access clinics abroad or pretend to be in a relationship with a woman. Additional obstacles arise for non-genetic fathers, during the process of gaining legal custody. Most of the obstacles gay men face throughout their path to parenthood can be understood in relation to heteronormativity. 


\section{ACKNOWLEDGEMENT}

We wish to express our gratitude to Sonja Höjerström for taking part in data collection and transcription; and to anonymous reviewers that provided valuable comments on previous versions of this article; and finally to all parents participating in the study.

ANNA malmquist (PhD) is an Associate Professor in Psychology at Linköping University. Her research has a main focus on LGBT families. Her doctoral thesis, Pride and Prejudice: Lesbian Families in Contemporary Sweden (2015), concerned lesbian motherhood. Presently she leads a research project on gay fatherhood in Sweden, alongside with a project on fear of childbirth in lesbian and bisexual women, and transgender people. Malmquist has also co-edited the first book in LGBT psychology published in Swedish, HBTQ+: Psykologiska perspektiv och bemötande (Natur och Kultur 2017).

ALEXANDER SPANBERG EKHOLM is a psychologist who graduated from Linköping University in spring 2018. His master's thesis, "Att vara normbrytande normativ: Gaypappors upplevelser av heteronormativitet, bemötande och juridik vid familjebildning” (2018), concerned gay fathers' paths to parenthood and focused on obstacles and opportunities for gay fathers in the Swedish society. Currently he is working as a school psychologist.

\section{REFERENCES}

Adoptionscentrum. 2017. "Adoptionscentrums första adoptionsförmedling till ett samkönat par." https://www.adoptionscentrum.se/sv/Nyhetsarkiv/adoptionscentrumsforsta-adoptionsformedling-till-ett-samkonat-par/.

Aldén, Lina, Lena Edlund, Mats Hammarstedt, and Michael Mueller-Smith. 2015. "Effect of Registered Partnership on Labor Earnings and Fertility for Same-Sex Couples: Evidence from Swedish Register Data." Demography 52.4:I243-68.

Andersen, Anna-Eva, Catherine Moberg, Anita Bengtsson Tops, and Pernilla Garmy. 2017. "Lesbian, Gay and Bisexual Parents' Experiences of Nurses' Attitudes in Child Health Care: A Qualitative Study." Journal of Clinical Nursing 26.23-24:5065-7I. 
Andreasson, Jesper, and Thomas Johansson. 2017. "It All Starts Now!: Gay Men and Fatherhood in Sweden." Journal of GLBT Family Studies 13.5:478-97.

Armesto, Jorge C., and Ester R. Shapiro. 20r r. "Adoptive Gay Fathers: Transformations of the Masculine Homosexual Self." Journal of GLBT Family Studies 7.I-2:72-92.

Arvidsson, Anna, Sara Johnsdotter, and Birgitta Essén. 2015. "Views of Swedish Commissioning Parents Relating to the Exploitation Discourse in Using Transnational Surrogacy.” PLoS ONE 10.5:eor26518. doi:10.1371/journal.pone.or26518.

Berkowitz, Dana. 20r r. “It Was the Cadillac of Adoption Agencies': Intersections of Social Class, Race, and Sexuality in Gay Men's Adoption Narratives." Journal of GLBT Family Studies 7.I-2:I09-3I.

Carneiro, Francis A., Fiona Tasker, Fernando Salinas-Quiroz, Isabel Leal, and Pedro A. Costa. 2017. "Are the Fathers Alright?: A Systematic and Critical Review of Studies on Gay and Bisexual Fatherhood." Frontiers in Psychology 8, Article no I636. https://doi.org/10.3389/fpsyg.2017.01636.

Charmaz, Kathy. 2014. Constructing Grounded Theory. London: Sage.

Charmaz, Kathy, and Karen Henwood. 20r7. "Grounded Theory Methods for Qualitative Psychology.” In The SAGE Handbook of Qualitative Research in Psychology, edited by Carla Willig and Wendy Stainton Rogers, 240-6o. Los Angeles: Sage.

Erera, Pauline I., and Dorit Segal-Engelchin. 20r4. "Gay Men Choosing to Co-Parent with Heterosexual Women.” Journal of GLBT Family Studies 10.5:449-74.

Folgerø, Tor. 2008. "Queer Nuclear Families?: Reproducing and Transgressing Heteronormativity." Journal of Homosexuality 54.I-2:I 24-49.

Goldberg, Abbie E., Jordan B. Downing, and April M. Moyer. 20r 2. "Why Parenthood, and Why Now?: Gay Men’s Motivations for Pursuing Parenthood.” Family Relations 61.I:I57-74.

Goldberg, Abbie E., and JuliAnna Z. Smith. 2014. "Perceptions of Stigma and SelfReported School Engagement in Same-Sex Couples with Young Children.” Psychology of Sexual Orientation and Gender Diversity I.3:202-I 2.

Golombok, Susan, and Fiona Tasker. 20I r. "Gay fathers." In The Role of the Father in Child Development, edited by Michael Lamb, 319-4r. Hoboken: Wiley.

Haverdahl, Anna-Lena. 2002. "Homosexuella vill ordna adoption själva." Svenska Dagbladet, October 26. https://www.svd.se/homosexuella-vill-ordna-adoption-sjalva.

Herz, Marcus, and Thomas Johansson. 2015. "The Normativity of the Concept of Heteronormativity." Journal of Homosexuality 62.8:1009-20.

Jonsson, Helen, and Ingrid Karrman. 2007. "Familjehem och sexualitet: Familjehemssekreterares resonemang kring familjehem bestående av homosexuella par.” Bachelor's thesis, Lund University.

Juvas, Sören, and Ulrika Westerlund. 2008. “Tillåt surrogatmödrar i Sverige: Annars åker folk utomlands.” Expressen, July i 7. https://www.expressen.se/debatt/ tillatsurrogatmodrar-i-sverige---annars-aker-folk-utomlands/. 
Malmquist, Anna. 2007. "Psykologförbundet och regnbågsfamiljerna: En diskursanalytisk studie av konfliktpunkter mellan Sveriges Psykologförbund och homosexuellas familjebildningar.” Master's thesis, Linköping University.

-. 2015. "Pride and Prejudice: Lesbian Families in Contemporary Sweden." PhD diss., Linköping University.

-. 2016. Lesbiska småbarnsföräldrar: Utmaningar i en tid av möjligheter. Gothenburg: Makadam.

Malmquist, Anna, and Karin Zetterqvist Nelson. 2008. "Diskursiv diskriminering av regnbågsfamiljer: En analys av argument mot likställande av homo- och heterosexuellas föräldraskap." Socialvetenskaplig tidskrift I5·3-4:3 I5-3 I.

Meyer, Ilan H. 2003. "Prejudice, Social Stress, and Mental Health in Lesbian, Gay, and Bisexual Populations: Conceptual Issues and Research Evidence." Psychological Bulletin $\mathrm{\text {2 } 2 9 . 5 : 6 7 4 - 9 7 .}$

Mägi, Erik, and Lina-lea Zimmerman. 2015. Stjärnfamiljejuridik: Svensk familjelagstiftning ur ett normkritiskt perspektiv. Malmö: Gleerups.

Nebeling Petersen, Michael. 2018. "Becoming Gay Fathers through Transnational Commercial Surrogacy.” Journal of Family Issues 39-3:693-7 I 9 .

Prop 2017/18:155. 2017. Modernare regler om assisterad befruktning och föräldraskap.

Rabun, Carl, and Ramona Faith Oswald. 2009. "Upholding and Expanding the Normal Family: Future Fatherhood through the Eyes of Gay Male Emerging Adults." Fathering 7:3:269-85.

SFS I949:38r. Föräldrabalken.

SFS 1985:367. Lag om internationella faderskapsfrågor.

SFS 2001:453. Socialtjänstlagen.

SFS 2006:35 I. Lag om genetisk integritet m.m.

Socialstyrelsen. 2014. Nationella adoptioner av barn i familjehem: En kartläggning av hur socialnämnderna uppmärksammar frägan. Stockholm.

SOU 20I6:I r. Olika vägar till föräldraskap: Slutbetänkande av utredningen om utökade möjligheter till behandling av ofrivillig barnlöshet. Stockholm.

Spånberg Ekholm, Alexander. 2018. "Att vara normbrytande normativ: Gaypappors upplevelser av heteronormativitet, bemötande och juridik vid familjebildning." Master's thesis, Linköping University.

Statistiska centralbyrån. 20I2. "Kärnfamiljen är fortfarande vanligast." http://www.scb.se/sv_/Hitta-statistik/Artiklar/Karnfamiljen-fortfarandevanligast/.

Statens medicinsk-etiska råd. 2013. Assisterad befruktning: Etiska aspekter. Stockholm: Fritze.

Thornberg, Robert, and Kathy Charmaz. 2013. "Grounded Theory and Theoretical Coding." In The SAGE Handbook of Qualitative Data Analysis, edited by Uwe Flick, 153-69. Los Angeles: Sage. 
Vinjamuri, Mohan. 2015. "Reminders of Heteronormativity: Gay Adoptive Fathers Navigating Uninvited Social Interactions.” Family Relations 64.2:263-77.

Zetterqvist Nelson, Karin. 2006. "Att vara pappa i homofamiljer: Berättelser om barn, mammor och familjeliv." Socialvetenskaplig tidskrift I3.r:66-86.

Ziv, Ido, and Yael Freund-Eschar. 2015. "The Pregnancy Experience of Gay Couples Expecting a Child through Overseas Surrogacy." Family Journal 23.2:158-66.

\section{SAMMANFATTNING}

Följande artikel fokuserar på hur gaypappor erfarit juridiska hinder då de blivit fäder och vilka strategier de använt för att hantera svårigheterna de mött. Studien baseras på semistrukturerade intervjuer för att fånga gaypappors egna erfarenheter av familjebildning. Deras berättelser har sedan analyserats med konstruktivistisk grundad teori (constructivist grounded theory). Totalt har trettio svenska gaypappor deltagit i studien. Deltagarna fick barn genom värdgraviditet (surrogatarrangemang), i delade föräldraskap med kvinnor, samt genom att vara familjehem. Juridiska hinder påverkade vägen till föräldraskap starkt. Några deltagare hade påbörjat försök att bli föräldrar på ett sätt (exempelvis genom att påbörja en adoptionsprocess), men sedan sökt andra vägar då den ursprungliga inte varit framgångsrik. För att lyckas bli föräldrar hade männen använt sig av flera strategier. Samtliga har varit envisa och väl förberedda. Några låtsades vara heterosexuella och flera använde utländska fertilitetskliniker. Oavsett vilken väg till föräldraskap de valt, betonade deltagarna att det hade krävts adekvata personliga eller ekonomiska resurser för att lyckas bli föräldrar. 